\title{
Effect of Tillage System and Organic Matter Management Interactions on Soil Chemical Properties and Biological Activity in a Spring Wheat Short-Time Cultivation
}

\author{
Barbara Breza-Boruta ${ }^{1}$, Karol Kotwica ${ }^{2}$ and Justyna Bauza-Kaszewska ${ }^{1, *(D)}$ \\ 1 Department of Microbiology and Food Technology, Faculty of Agriculture and Biotechnology, \\ Bydgoszcz University of Science and Technology, 6 Bernardynska Street, 85-029 Bydgoszcz, Poland; \\ breza@pbs.edu.pl \\ 2 Department of Agronomy, Faculty of Agriculture and Biotechnology, Bydgoszcz University of Science and \\ Technology, 7 Prof. S. Kaliskiego Street, 85-796 Bydgoszcz, Poland; kotwica@pbs.edu.pl \\ * Correspondence: bauza@pbs.edu.pl
}

check for updates

Citation: Breza-Boruta, B.; Kotwica, K.; Bauza-Kaszewska, J. Effect of Tillage System and Organic Matter Management Interactions on Soil Chemical Properties and Biological Activity in a Spring Wheat Short-Time Cultivation. Energies 2021, 14, 7451. https://doi.org/10.3390/ en14217451

Academic Editor: Attilio Converti

Received: 28 September 2021

Accepted: 4 November 2021

Published: 8 November 2021

Publisher's Note: MDPI stays neutral with regard to jurisdictional claims in published maps and institutional affiliations.

Copyright: (c) 2021 by the authors. Licensee MDPI, Basel, Switzerland. This article is an open access article distributed under the terms and conditions of the Creative Commons Attribution (CC BY) license (https:/ / creativecommons.org/licenses/by/ $4.0 /)$.

\begin{abstract}
Properly selected tillage methods and management of the available organic matter resources are considered important measures to enable farming in accordance with the principles of sustainable agriculture. Depending on the depth and intensity of cultivation, tillage practices affect soil chemical composition, structure and biological activity. The three-year experiment was performed on the soil under spring wheat (cv. Tybalt) short-time cultivation. The influence of different tillage systems and stubble management on the soil's chemical and biological parameters was analyzed. Organic carbon content (OC); content of biologically available phosphorus (Pa), potassium $(\mathrm{Ka})$, and magnesium (Mg); content of total nitrogen ( $\mathrm{TN})$, mineral nitrogen forms: $\mathrm{N}-\mathrm{NO}_{3}$ and $\mathrm{N}-\mathrm{NH}_{4}$ were determined in various soil samples. Moreover, the total number of microorganisms (TNM), bacteria (B), actinobacteria (A), fungi (F); soil respiratory activity (SR); and $\mathrm{pH}$ in $1 \mathrm{M} \mathrm{KCl}$ $(\mathrm{pH})$ were also investigated. The results show that organic matter amendment is of greater influence on soil characteristics than the tillage system applied. Manure application, as well as leaving the straw in the field, resulted in higher amounts of organic carbon and biologically available potassium. A significant increase in the number of soil microorganisms was also observed in soil samples from the experimental plots including this procedure.
\end{abstract}

Keywords: agricultural practices; tillage intensity; stubble management; sustainable agriculture; soil; nutrients; microorganisms

\section{Introduction}

The idea of sustainable agriculture, aimed at limiting the negative impact of agricultural practice on the natural environment, with simultaneous maintenance of the production profitability, is associated with many technological, economic, and social challenges [1]. The increase in food production, which is a natural consequence of the increase in the world's population, has led to the intensification of agricultural practices, especially regarding the cultivation of plants that are the basis of human nutrition in various regions of the world [2]. The traditional cultivation methods used for this purpose, especially those based on deep plowing and other treatments that strongly interfere with the soil structure, lead to its gradual degradation [3]. The negative effects of traditional plowing include, among others, increasing the susceptibility of soil to the erosion process, accelerating the mineralization of soil organic matter, and limiting its biodiversity [3,4]. The present study is a contribution to the literature in that it helps the farmers to assess and select the optimal tillage intensity level, providing a balance between environmental and economic benefits.

Tillage systems alternative to plowing, based on modifications in plant rotation, fertilization, and limiting or eliminating agrotechnical treatments (e.g., no-till system) may 
significantly affect the condition of the soil, as well as the size and quality of the crop, and eliminate the undesirable effects of intensive agricultural activity $[5,6]$. However, the results of the research in this area are ambiguous and demonstrate that not in every case the introduction of such modifications has a positive effect on all key indicators of soil quality $[7,8]$. The use of a no-till cultivation system is considered to be one of the foundations of sustainable agriculture [9]. The effect of simplification of tillage treatments on the physical and chemical properties of the soil depends on the habitat conditions, including temperature, humidity, or rainfall, and on the usage duration of the selected cultivation system $[10,11]$. It turns out that despite the presumed positive impact of tillage simplification on soil properties, similarly to excessive intensification, such treatment may result in unfavorable changes in the structural properties of soil, especially density and firmness, and in a reduction in its fertility due to phosphorus and organic matter losses [2].

The optimization of the cultivation system, however, cannot focus solely on determining the appropriate frequency and intensity of agrotechnical treatments. This process should also consider the content of organic matter in the soil that determines the ability of the soil to retain water and nutrients, its proper structure, and biological activity [3]. In modern agriculture, it is often necessary to supplement the deficiencies of organic matter in the soil by introducing organic carbon-rich crop residues, straw, or intercrop biomass into it [12]. Low content of organic matter is often found in arable soils in areas characterized by a high share of cereals in the structure of sown crops. It is estimated that to meet the nutritional needs of the human population, whose number according to FAO will increase by $30 \%$ by 2050 , the production of cereals must rise annually by at least $1.1 \%$. The world production of wheat-a cereal with the largest area of cultivation-has maintained an upward trend for years and will amount to over 780 million tons in 2021 [13,14]. Taking into account the negative impact of cereals on the amount of soil organic matter, enrichment of soil with additional sources of organic matter seems justified.

The aim of this study was to analyze the effect of the tillage system and method of incorporating post-harvest residues into the soil on (i) its chemical properties, including $\mathrm{pH}$, organic carbon, total and mineral nitrogen, magnesium $(\mathrm{Mg})$, potassium $(\mathrm{K})$, and phosphorous (P), and (ii) the content of various groups of soil microorganisms in shorttime spring wheat cultivation.

It was assumed that introducing various forms of organic matter into the soil (manure, straw, catch crops), accompanying different tillage methods, alleviates the negative effects of spring wheat and short-time cultivation. It was also predicted that the application of Effective Microorganisms (EM) preparations affects beneficially the parameters tested in the study, which in view of ambiguous results of previous studies should be verified.

\section{Literature Review}

Introducing sustainable agriculture into practice concerns various aspects of life and the economy. From the economic point of view, cultivation systems based on minimizing the number and intensity of agrotechnical treatments (reduced-tillage) or eliminating them completely (zero/no-tillage) can bring benefits by reducing energy consumption and production costs without significantly affecting the yield of crops [15,16]. Moitzi et al. [17] reported that a no-tillage system required considerably lower energy input compared to moldboard plough and deep conservation tillage systems. The reduced-tillage systems save labor, fuel, and machinery costs [18] Moreover, based on minimal soil inversion, those systems help to reduce the level of soil organic matter (SOM) oxidation by reducing $\mathrm{CO}_{2}$ emissions to the atmosphere, which justifies the implementation of these practices due to the potential environmental benefits [19]. The reduction in $\mathrm{CO}_{2}$ emission can be also achieved by a decrease in fuel consumption in reduced tillage systems [20].

Besides the economic and ecological effects, the simplification of agrotechniques can also significantly improve the structure and chemical composition of the soil, including the content of organic carbon (SOC) that determines the proper functioning of the soil environment, water, and mineral management, or soil biological activity [6,21-24]. Soil 
supplementation in organic amendments and animal manure significantly increases the content of organic carbon and organic matter-both in terms of its amount, composition, and proportion of individual component fractions [25].

The importance of soil microorganisms for the proper functioning of this ecosystem is beyond question. Bacteria, actinomycetes, and fungi are responsible for the course of key biochemical processes that affect the soil and its components, at the same time affecting the yield size and plant health [26,27]. Moreover, their cells, both living or dead, are part of the soil organic matter [28,29]. Different tillage techniques affect the structure of the soil microbial community [30]. As reported by Buerkert et al. [31], a reduction in tillage intensity stimulates the development of fungi, while increased land-use intensity (tillage, fertilization) promotes the growth of bacteria.

When analyzing the potential methods of supplementing the soil with organic matter, the possibility of using crop residues should be considered. Leaving straw in the field after the cultivation of cereal crops allows for its effective management, following the idea of sustainable agriculture, additionally resulting in levelling the deficiencies of organic matter in the soil [3,32]. Powlson et al. [32] revealed that the mean annual increase in SOC resulting from the addition of cereal straw reached $50 \pm 15 \mathrm{C} \mathrm{kg} \mathrm{ha}^{-1} \mathrm{yr}^{-1} \mathrm{t}^{-1}$. Crop residues left on the soil surface in reduced tillage systems undergo decomposition, resulting in microbial activity increase near the soil surface [33].

While the introduction of organic fertilizers or straw into the soil is a commonly used agricultural practice, a relatively less popular way to improve the properties of arable soils is to supplement them with microbiological preparations [34,35]. The most commonly used biopreparations are consortia of the so-called effective microorganisms (EM), positively influencing the soil environment, its biodiversity, and physico-chemical characteristics, and, consequently, the amount and quality of crops yield. However, the results of the research focused on the effectiveness of EM application are highly divergent.

\section{Materials and Methods}

\subsection{Experiment Location}

The three-year field experiment was performed on an individual farm in Chelmce, the Kuyavian-Pomeranian Voivodship, Poland $\left(52^{\circ} 61^{\prime} \mathrm{N} ; 18^{\circ} 44^{\prime}\right.$ E). The static (2nd and 3rd year of spring wheat short-time cultivation) three-way experiment in three replications was set up in a split-plot-split-block design.

The experimental factors were:

T- tillage system (six variants):

1- skimming of the stubble field, pre-winter ploughing followed by seeder-cultivator unit in spring;

2- manure, skimming, pre-winter ploughing followed by seeder-cultivator unit in spring;

3- grubbing of the stubble field, grubbing followed by seeder-cultivator unit in spring;

4- grubbing of the stubble field combined with stubble catch crop, grubbing followed by seeder-cultivator unit in spring;

5- grubbing of the stubble field combined with stubble catch crop, sow ploughing followed by seeder-cultivator unit in spring;

6- manure, skimming combined with stubble catch crop, grubbing followed by seedercultivator unit in spring.

The Gregoire-Besson 5-furrow reversible plough was used; the plowing depth was $25 \mathrm{~cm}$. The spring wheat (Triticum aestivum L.) cv. Tybalt-qualified seed material was used in the experiment in March 2012 and April 2013. Wheat sowing density was 450 grains. $\mathrm{m}^{-2}$. The sowing depth was $4 \mathrm{~cm}$, and the row spacing was $14.3 \mathrm{~cm}$. Cattle solid manure was applied at a dose of $30 \mathrm{t} \cdot \mathrm{ha}^{-1}$. The stubble catch crop was white mustard (Sinapis alba L.) sown in mid-August.

$\mathrm{S}$ - stubble management (four variants): 
1- leaving the shredded straw;

2- leaving shredded straw combined with EM application;

3- removing straw combined with EM application;

4- removing straw.

EM-preparation containing effective microorganisms "EM-A" (Greenland Technologia EM Sp. Z o.o.) was applied at a dose of $40 \mathrm{dm}^{3} \cdot \mathrm{ha}^{-1}$. According to the general information provided by the manufacturer, the preparations consisted of synergistically active cultures of bacteria of the Azotobacter genus, lactic acid bacteria, yeast, phototrophic bacteria, actinomycetes, fungi and other beneficial microorganisms found in the natural environment. More specific and detailed data were not included.

An experimental plot with a classic tillage method was considered as the control, with the following combination of experimental factors: skimming of the stubble field, pre-winter ploughing (variant T.1), made after removing the straw without the use of EM (S.4). The chemical properties of light loam soil sampled in 2011 were as follows: $\mathrm{pH}$ in $1 \mathrm{M} \mathrm{KCl}(\mathrm{pH}) 7.6$, organic carbon content (OC) $2.43 \%$, content of available phosphorus ( $\mathrm{Pa}$ ), potassium (Ka), and magnesium $(\mathrm{Mg})$ : $17.3,20.4$, and $5.10 \mathrm{mg} 100 \mathrm{~g}^{-1}$, respectively.

Habitat conditions during the performance of the research, including the distribution of rainfall and temperature, as well as agrotechnical conditions and wheat yielding, were described in the previous paper [36].

\subsection{Soil Samples}

Ten soil samples were collected individually from each experimental plot for all the treatments. The soil from a single plot was thoroughly mixed to create a pooled sample. All soil samples were analyzed in triplicates. Soil samples for microbiological analyses were collected for the first time in 2011, at the beginning of the experiment (after harvesting the forecrop and before stubble cultivation), and the last time in 2013, after plant harvesting and before the beginning of post-harvest cultivation. On each plot, soil samples were taken from the tilled soil layer (0-25 cm depth).

Soil samples for chemical analyses, including the measurement of soil $\mathrm{pH}$, the content of organic carbon $(\mathrm{OC})$, total nitrogen $(\mathrm{TN})$, and available $\mathrm{P}(\mathrm{Pa}), \mathrm{K}(\mathrm{Ka})$, and $\mathrm{Mg}(\mathrm{Mg})$ forms in individual experimental plots, were collected from a depth of $0-25 \mathrm{~cm}$, on the dates analogous to microbiological tests.

The content of mineral nitrogen and its forms was determined in the autumn and spring seasons in the following years of research based on average samples; from three replications from each experimental plot.

\subsection{Chemical Analyses}

Selected physicochemical soil properties i.e., $\mathrm{pH}$ in $1 \mathrm{M} \mathrm{KCl}$ using the potentiometric method [37], organic carbon (OC), and total nitrogen (TN) concentrations were estimated in air-dried disturbed soil samples sieved through a $2 \mathrm{~mm}$ mesh, with a Vario Max CN analyzer (Elementar Analysensysteme $\mathrm{GmbH}$, Langenselbold, Germany). The contents of available forms of phosphorus ( $\mathrm{Pa}$ ) [38] and potassium (Ka) were determined by the Egner-Riehm method [39], while the content of plant-available magnesium (Mg) was analyzed following the Schachtschabel method [40]. The content of plant-available forms was determined by atomic absorption spectroscopy and atomic emission spectroscopy using a Solaar S4 spectrometer. The forms of mineral nitrogen, i.e., ammonium $\left(\mathrm{N}^{-\mathrm{NH}_{4}}\right)$ and nitrate $\left(\mathrm{N}-\mathrm{NO}_{3}\right)$, were determined by flow colorimetry following soil extraction in $1 \%$ $\mathrm{K}_{2} \mathrm{SO}_{4}$ using the Skalar San Plus Analyzer.

Based on the obtained values of selected chemical parameters (soil $\mathrm{pH}$, content of $\mathrm{OC}$, $\mathrm{TN}$, and available $\mathrm{P}, \mathrm{K}$, and $\mathrm{Mg}$ forms) at two dates-before the start of the research and after its completion, the relative change index $\left(\mathrm{W}_{\mathrm{z}}\right)$ was determined. The $\mathrm{W}_{\mathrm{z}}$ index was calculated as the quotient of the value of a specific chemical parameter at the beginning and the end of research in a given experimental plot. The values of the index above 1.0 indicate 
a favorable impact of a given combination of levels of the analyzed factors, and the values lower than 1.0 on the contrary.

\subsection{Microbiological Analyses}

To determine the total number of aerobic heterotrophic bacteria, actinobacteria, and filamentous fungi, the plate count method was applied. In order to prepare ten-fold serial dilutions of the soil samples $\left(10^{-1}\right.$ to $\left.10^{-6}\right)$, ten-gram samples of each soil investigated were added to $90 \mathrm{~mL}$ of sterile Ringer's solution. The prepared soil solutions were inoculated on the selective growth media. A yeast extract-peptone-soil extract medium (YPS) was used to estimate the total number of bacteria (B) [41]. Actinobacteria (A) isolation was carried out on yeast extract glucose agar (YGA) with $100 \mu \mathrm{g} \mathrm{mL}^{-1}$ nystatin [42] while filamentous fungi (F) on Rose-Bengal agar with $30 \mu \mathrm{g} \mathrm{mL}{ }^{-1}$ streptomycin [41]. Microbial cultures were incubated at $25^{\circ} \mathrm{C}$ for five (bacteria and fungi) or ten days (actinobacteria). All analyzes were performed in four replications. After the incubation period, the colonies of the microorganisms were counted. Finally, the number of colony-forming units (cfus) was calculated per $1 \mathrm{~g}$ of soil dry matter ( $\mathrm{cfu} \mathrm{g}^{-1}$ d.m. of soil).

Based on the total number of microorganisms, the relative change index $\left(\mathrm{W}_{\mathrm{k}}\right)$ was determined. The $W_{k}$ index was calculated as the quotient of the value of the mean number of microorganisms from the individual experimental plots and in a control plot. The values of the index above 1.0 indicate a favorable impact of a given combination of levels of the analyzed factors, and the values lower than 1.0-on the contrary.

\subsection{Soil Respiration Measurement}

Soil biological activity was measured based on the analysis of soil respiration intensity performed in each year of the study, at four dates each year, using the SRC-1 Soil Respiration Chamber with the PP Systems EGM-4 analyzer. The intensity of respiration was determined by changes in the concentration of carbon dioxide, measured in 5-min cycles, in each experimental plot.

\subsection{Economic Calculations}

The assessment of the impact of the applied tillage systems and stubble management on the economic effect of spring wheat cultivation was based on standard gross margin (SGM) values, calculated by subtracting from the output (average amount and value of the obtained crops) the variable cost (seeds, fertilizers, crop protection) of spring wheat in the various cultivation systems. Analyses were performed according to the methodological assumptions of the Polish Farm Accountancy Data Network (FADN) [43].

\subsection{Data Analysis}

The final results are mean of three replications from each experimental plot in each sampling time. Soil characteristics data were normally distributed, and the results were statistically analyzed using the analysis of variance of multiple experiments, according to the model appropriate for the randomized subblock design. Analysis of variance (two-way ANOVA) was used, where the first factor was the tillage systems ( $\mathrm{T}$ ) and the second was the method of managing post-harvest residues (S). The significance of differences between the plot means was determined by Tukey's test, at $p \leq 0.05$. The principal component analysis (PCA) was applied to evaluate the studied soil parameters. The results of this analysis are shown as graphics that display traits in the configuration of the first two principal components (PC1 and PC2), which synthetically represent mutually correlated variables. The similarity of the impact of experimental factors ( $\mathrm{T}$ tillage methods, $\mathrm{S}$ stubble management) on the chemical and biological soil features was assessed by cluster analysis using Ward's method and presented in a dendrogram. Due to the diverse ranges of absolute quantities of individual soil parameters, multidimensional analyses were carried out on standardized data. The Statistica.PL 12 [44] software package was used for statistical analysis in the study. 


\section{Results}

The results of the research show that the addition of manure or catch crop has a much greater effect on the content of organic carbon in the soil than the tillage system. The OC content in all cultivation plots ranged from 12.7 to $32.1 \mathrm{OC} \mathrm{g} \mathrm{kg}^{-1} \mathrm{~d} . \mathrm{m}$. soil (Table 1). In the combinations T.1 (traditional plowing tillage) and T.3 (tillage limited to grubbing), the values of the coefficient of relative change in the amount of OC were lower than 1 , which indicates a decrease in the amount of organic carbon in these plots (Table 1). The average amounts of organic carbon were higher in the experimental plots S.1 and S.2, where the stubble was managed by introducing straw into the soil. In the experimental plots with the removal of straw $(\mathrm{S} .3, \mathrm{~S} .4)$, lower values of the coefficient of relative change in the amount of OC were found than after introducing straw to the soil. The mean total nitrogen content in the studied soils varied from 1.68 to $2.50 \mathrm{~N} \mathrm{~g} \mathrm{~kg}^{-1} \mathrm{~d}$.m. soil. After introducing manure and catch crop into the soil (T.6), the values of the index of the relative change in nitrogen content exceeded 1, regardless of the method of stubble management. Both, the average OC content and the TN content were the lowest in the T.3 tillage system limited to grubbing (Table 1).

Table 1. Soil organic carbon OC and total nitrogen $\mathrm{TN}\left(\mathrm{g} \mathrm{kg}^{-1}\right)$ content, depending on the tillage method (factor T) and stubble management (factor $\mathrm{S}$ ) in spring wheat cultivation.

\begin{tabular}{|c|c|c|c|c|c|c|c|c|c|}
\hline \multirow{3}{*}{$\begin{array}{l}\text { Factor } \mathrm{T} \\
\text { Variants }\end{array}$} & \multicolumn{8}{|c|}{ Factor S Variants } & \multirow{3}{*}{ Mean } \\
\hline & \multicolumn{2}{|c|}{1} & \multicolumn{2}{|c|}{2} & \multicolumn{2}{|c|}{3} & \multicolumn{2}{|c|}{4} & \\
\hline & Content & $\mathbf{W}_{\mathbf{z}}$ & Content & $\mathbf{W}_{\mathbf{z}}$ & Content & $\mathbf{W}_{\mathbf{z}}$ & Content & $\mathbf{W}_{\mathbf{z}}$ & \\
\hline \multicolumn{10}{|c|}{ Organic Carbon-OC (C g kg ${ }^{-1}$ d.m. soil) } \\
\hline 1 & 16.7 & 1.00 & 30.8 & 1.02 & 22.9 & 0.99 & 17.1 & 0.98 & 21.9 \\
\hline 2 & 25.9 & 1.04 & 24.7 & 1.06 & 28.4 & 1.02 & 20.6 & 1.06 & 24.9 \\
\hline 3 & 12.7 & 1.02 & 28.8 & 1.02 & 18.4 & 0.98 & 16.5 & 0.98 & 19.1 \\
\hline 4 & 31.1 & 1.04 & 21.5 & 1.06 & 21.1 & 1.01 & 25.0 & 1.00 & 24.7 \\
\hline 5 & 32.1 & 1.03 & 18.9 & 1.03 & 21.5 & 1.01 & 24.6 & 1.00 & 24.3 \\
\hline 6 & 31.1 & 1.05 & 21.5 & 1.06 & 20.8 & 1.01 & 25.0 & 1.00 & 24.6 \\
\hline Mean & 24.9 & & 24.4 & & 22.2 & & 21.5 & & \\
\hline \multicolumn{10}{|c|}{ Total Nitrogen-TN ( $\mathrm{N} \mathrm{g} \mathrm{kg}^{-1}$ d.m. soil) } \\
\hline 1 & 1.43 & 0.96 & 2.89 & 1.01 & 1.97 & 0.96 & 1.46 & 0.96 & 1.94 \\
\hline 2 & 2.22 & 1.00 & 2.21 & 1.12 & 3.10 & 1.24 & 1.84 & 1.08 & 2.34 \\
\hline 3 & 1.08 & 1.03 & 2.49 & 1.04 & 1.74 & 0.92 & 1.41 & 0.97 & 1.68 \\
\hline 4 & 2.61 & 0.95 & 2.05 & 1.07 & 1.77 & 0.99 & 2.59 & 0.96 & 2.25 \\
\hline 5 & 3.29 & 0.83 & 1.93 & 0.91 & 1.97 & 0.89 & 2.82 & 1.09 & 2.50 \\
\hline 6 & 1.55 & 1.09 & 3.07 & 1.06 & 1.83 & 1.04 & 2.21 & 1.02 & 2.16 \\
\hline Mean & 2.03 & & 2.44 & & 2.06 & & 2.05 & & \\
\hline
\end{tabular}

Factor T levels: 1—skimming of the stubble field, pre-winter ploughing followed by seeder-cultivator unit in spring, 2-manure, skimming, pre-winter ploughing followed by seeder-cultivator unit in spring, 3-grubbing of the stubble field, grubbing followed by seeder-cultivator unit in spring, 4-grubbing of the stubble field + stubble catch crop, grubbing followed by seeder-cultivator unit in spring, 5-grubbing of the stubble field + stubble catch crop, sow ploughing followed by seeder-cultivator unit in spring, 6-manure, skimming + stubble catch crop, grubbing followed by seeder-cultivator unit in spring; Factor S levels: 1—leaving the shredded straw, 2-leaving shredded straw combined with EM application, 3-removing straw combined with EM application, 4-removing straw.

During the autumn season, the chemical analyses of individual forms of mineral nitrogen in the soil. N-NH4${ }^{+}$and $\mathrm{N}_{-} \mathrm{NO}_{3}$ revealed their high content in the experimental plots where the traditional tillage system (T.2), including manure application, skimming, and pre-winter ploughing, was used. Significantly higher values of the mean content of total mineral nitrogen (TMN) in the soil, exceeding $50 \mathrm{mg} \mathrm{N} \mathrm{kg}^{-1}$, were also observed with a conventional tillage system combined with manure fertilization (T.2). The mean amounts of TMN in other experimental plots ranged from 37.5 to $44.7 \mathrm{~N} \mathrm{mg} \mathrm{kg}^{-1}$ and were not significantly different (Table 2). 
Table 2. Content of $\mathrm{N}-\mathrm{NH}_{4}, \mathrm{~N}-\mathrm{NO}_{3}$, and total mineral nitrogen (TMN) $\left(\mathrm{mg} \mathrm{kg}^{-1}\right)$ in the soil, depending on the tillage method (factor $\mathrm{T}$ ) and stubble management (factor $\mathrm{S}$ ) under spring wheat cultivation in autumn and spring.

\begin{tabular}{|c|c|c|c|c|c|c|c|c|c|c|}
\hline \multirow{2}{*}{$\begin{array}{c}\text { Factor T } \\
\text { Variants * }\end{array}$} & \multicolumn{10}{|c|}{ Factor S Variants } \\
\hline & 1 & 2 & 3 & 4 & Mean & 1 & 2 & 3 & 4 & Mean \\
\hline & \multicolumn{5}{|c|}{ autumn } & \multicolumn{5}{|c|}{ spring } \\
\hline & \multicolumn{10}{|c|}{$\mathrm{N}-\mathrm{NH}_{4}\left(\mathrm{mg} \mathrm{kg}^{-1}\right)$} \\
\hline 1 & 15.6 & 13.3 & 15.1 & 16.5 & 15.1 & 21.0 & 21.4 & 21.4 & 15.6 & 19.9 \\
\hline 2 & 21.4 & 21.1 & 21.8 & 22.4 & 21.7 & 28.0 & 28.4 & 27.5 & 27.4 & 27.8 \\
\hline 3 & 17.3 & 16.3 & 16.6 & 19.0 & 17.3 & 19.4 & 20.8 & 20.0 & 17.2 & 19.3 \\
\hline 4 & 17.1 & 15.0 & 15.1 & 16.7 & 16.0 & 27.3 & 28.2 & 26.5 & 26.4 & 27.1 \\
\hline 5 & 16.1 & 14.7 & 14.8 & 18.0 & 15.9 & 27.3 & 27.8 & 27.4 & 26.4 & 27.2 \\
\hline 6 & 19.5 & 18.9 & 19.8 & 21.1 & 19.8 & 30.5 & 33.6 & 28.2 & 28.2 & 30.1 \\
\hline \multirow[t]{2}{*}{ Mean } & 17.8 & 16.5 & 17.2 & 19.0 & & 25.6 & 26.7 & 25.2 & 23.5 & \\
\hline & \multicolumn{10}{|c|}{$\mathrm{N}-\mathrm{NO}_{3}\left(\mathrm{mg} \mathrm{kg}^{-1}\right)$} \\
\hline 1 & 24.8 & 16.7 & 26.4 & 28.1 & 24.0 & 11.9 & 12.2 & 10.9 & 10.5 & 11.4 \\
\hline 2 & 32.5 & 30.3 & 30.5 & 33.8 & 31.8 & 26.1 & 26.3 & 25.8 & 24.3 & 25.6 \\
\hline 3 & 26.6 & 20.5 & 30.8 & 31.7 & 27.4 & 13.6 & 14.9 & 13.7 & 11.6 & 13.5 \\
\hline 4 & 20.9 & 20.9 & 21.9 & 22.5 & 21.5 & 23.5 & 23.9 & 22.5 & 20.4 & 22.6 \\
\hline 5 & 21.3 & 20.7 & 21.9 & 23.2 & 21.8 & 23.5 & 24.0 & 24.7 & 19.5 & 22.9 \\
\hline 6 & 24.1 & 23.9 & 25.6 & 25.8 & 24.9 & 26.3 & 27.2 & 26.9 & 24.2 & 26.1 \\
\hline Mean & 25.0 & 22.2 & 26.2 & 27.5 & & 20.8 & 21.4 & 20.7 & 18.4 & \\
\hline \multicolumn{11}{|c|}{$\mathrm{TMN}$} \\
\hline 1 & 40.4 & 30.0 & 41,5 & 44.7 & 39.1 & 33.0 & 33.7 & 32.3 & 26.0 & 31.2 \\
\hline 2 & 53.9 & 51.6 & 52.3 & 56.2 & 53.5 & 54.1 & 54.8 & 53.2 & 51.6 & 53.4 \\
\hline 3 & 43.9 & 36.8 & 47.5 & 50.7 & 44.7 & 33.0 & 35.8 & 33.7 & 28.8 & 32.8 \\
\hline 4 & 38.0 & 35.9 & 37.0 & 39.2 & 37.5 & 50.8 & 52.1 & 49.0 & 46.8 & 49.7 \\
\hline 5 & 37.4 & 35.3 & 36.6 & 41.2 & 37.6 & 50.8 & 51.8 & 52.1 & 45.9 & 50.7 \\
\hline 6 & 43.5 & 42.8 & 45.4 & 46.9 & 44.7 & 56.7 & 60.8 & 55.1 & 52.3 & 56.2 \\
\hline Mean & 42.9 & 38.7 & 43.4 & 46.5 & & 46.4 & 48.1 & 45.9 & 41.9 & \\
\hline \multicolumn{6}{|c|}{$\begin{array}{l}\mathrm{LSD}_{0.05} \text { for: Factor } \mathrm{T}=8.7 ; \text { Factor } \mathrm{S}=4.2 ; \\
\text { Interaction } \mathrm{T} / \mathrm{S}=\text { n.s.; } \mathrm{S} / \mathrm{T}=\text { n.s. }{ }^{* *}\end{array}$} & \multicolumn{5}{|c|}{$\begin{array}{l}\mathrm{LSD}_{0.05} \text { for: Factor } \mathrm{T}=8.5 ; \text { Factor } \mathrm{S}=3.9 \\
\text { Interaction } \mathrm{T} / \mathrm{S}=\text { n.s. } \mathrm{S} / \mathrm{T}=\text { n.s. }\end{array}$} \\
\hline
\end{tabular}

* See: Table $1,{ }^{* *}$ n.s. - not significant, the significance of differences by Tukey's test, at $p \leq 0.05$.

The research performed in the spring period showed the highest, but not significantly different from all the remaining experimental variants, content of the tested forms of mineral nitrogen in the tillage system T.6, in which plowing was accompanied by the introduction into the soil the catch crops and manure as the additional source of organic matter. The significantly lower, compared to other systems, amounts of the nitrate form of nitrogen $\mathrm{N}-\mathrm{NO}_{3}$ were reported in the soil in traditional plowing tillage (T.1) and tillage limited to grubbing (T.3). The mean content of total mineral nitrogen in the soil samples from these experimental plots slightly exceeded $30 \mathrm{~N} \mathrm{mg} \mathrm{kg}^{-1} \mathrm{~d} . \mathrm{m}$. soil and was significantly lower compared to the other experimental plots, where it reached $56.2 \mathrm{~N} \mathrm{mg} \mathrm{kg}^{-1} \mathrm{~d}$.m. soil (T.6) (Table 2).

The obtained results did not show a clear influence of the introduction of straw and the EM bacterial preparation on the content of mineral nitrogen in the studied soils. A statistically lower value of this parameter was found in the soil from the experimental plot without straw and EM (S.4) in spring compared to the other experimental combinations (Table 2).

The highest values of the mean content of $\mathrm{P}$ and $\mathrm{K}$ were 205.2 and $409.9 \mathrm{mg} \mathrm{kg}{ }^{-1} \mathrm{~d} . \mathrm{m}$. soil, respectively. They were found in soils from the experimental plot T.6, where fertilization with manure and catch crop were applied. A non-significantly lower concentration of both of these elements in the soil was reported when manure was used in plowing cultivation (T.2). It was also found that only in these two experimental variants (T.2, T.6), 
the coefficient of relative change in the content of $P$ in the soil exceeded 1.0, which means that the use of the other cultivation systems decreased the content of this element in the soil during the entire research cycle or had no effect on it. A similar situation occurred with the value of the coefficient of the relative change in the content of $\mathrm{Mg}$ in soil. The mean amount of this element, however, showed lower differentiation between the experimental plots used compared to $\mathrm{P}$ and $\mathrm{K}$, and it ranged from 43.5 to $47.7 \mathrm{mg} \mathrm{kg}^{-1} \mathrm{~d}$.m. soil. The soil $\mathrm{K}$ content analysis revealed that, in contrast to $\mathrm{P}$ and $\mathrm{Mg}$, an increase in its value was reported in most experimental variants, with a relative change coefficient $>1$. It was also found that with stubble management based on introducing shredded straw into the soil (S.1, S.2), the value of this coefficient increased, reaching 1.22 (Table 3).

Table 3. Soil phosphorus Pa, potassium Ka, and magnesium $\mathrm{Mg}\left(\mathrm{mg} \mathrm{kg}^{-1}\right.$ d.m.) content, and $\mathrm{pH}$ of the soil, depending on tillage method (factor $\mathrm{T}$ ) and stubble management (factor $\mathrm{S}$ ) in spring wheat cultivation.

\begin{tabular}{|c|c|c|c|c|c|c|c|c|c|}
\hline \multirow{3}{*}{$\begin{array}{l}\text { Factor T } \\
\text { Variants * }\end{array}$} & \multicolumn{8}{|c|}{ Factor S Variants } & \multirow{3}{*}{ Mean } \\
\hline & \multicolumn{2}{|c|}{1} & \multicolumn{2}{|c|}{2} & \multicolumn{2}{|c|}{3} & \multicolumn{2}{|c|}{4} & \\
\hline & Content & $\mathbf{W}_{\mathbf{z}}$ & Content & $\mathbf{W}_{\mathbf{z}}$ & Content & $\mathbf{W}_{\mathbf{z}}$ & Content & $\mathbf{W}_{\mathbf{z}}$ & \\
\hline \multicolumn{10}{|c|}{ Phosphorus-Pa (mg kg ${ }^{-1}$ d.m. soil) } \\
\hline 1 & 185.0 & 1.00 & 189.6 & 0.99 & 187.8 & 0.98 & 187.9 & 0.99 & 187.6 \\
\hline 2 & 193.2 & 1.11 & 206.8 & 1.11 & 213.1 & 1.10 & 202.9 & 1.09 & 204.0 \\
\hline 3 & 189.2 & 0.99 & 188.3 & 0.99 & 188.1 & 0.98 & 196.3 & 0.99 & 190.5 \\
\hline 4 & 182.7 & 0.98 & 186.3 & 0.98 & 179.9 & 0.97 & 183.2 & 0.97 & 183.0 \\
\hline 5 & 193.2 & 0.99 & 181.2 & 0.98 & 178.5 & 0.97 & 184.2 & 0.97 & 184.3 \\
\hline 6 & 207.9 & 1.11 & 206.8 & 1.11 & 202.9 & 1.09 & 203.1 & 1.09 & 205.2 \\
\hline Mean & 191.9 & & 193.2 & & 191.7 & & 192.9 & & \\
\hline \multicolumn{10}{|c|}{ Potassium-Ka (mg kg ${ }^{-1}$ d.m. soil) } \\
\hline 1 & 387.5 & 1.11 & 388.1 & 1.10 & 366.2 & 1.01 & 358.9 & 1.03 & 375.2 \\
\hline 2 & 421.3 & 1.22 & 418.1 & 1.21 & 389.4 & 1.11 & 392.3 & 1.11 & 405.3 \\
\hline 3 & 389.1 & 1.10 & 384.9 & 1.08 & 328.9 & 1.01 & 359.8 & 1.03 & 365.7 \\
\hline 4 & 392.6 & 1.09 & 379.9 & 1.08 & 348.9 & 1.00 & 347.2 & 1.00 & 367.1 \\
\hline 5 & 384.5 & 1.08 & 379.3 & 1.08 & 349.1 & 0.99 & 348.2 & 1.00 & 365.3 \\
\hline 6 & 429.6 & 1.22 & 425.8 & 1.20 & 396.2 & 1.11 & 388.0 & 1.11 & 409.9 \\
\hline Mean & 400.7 & & 396.0 & & 363.1 & & 365.7 & & \\
\hline \multicolumn{10}{|c|}{ Magnesium-Mg (mg kg ${ }^{-1}$ d.m. soil) } \\
\hline 1 & 42.3 & 0.99 & 48.9 & 0.99 & 39.2 & 0.98 & 43.5 & 0.98 & 43.5 \\
\hline 2 & 48.6 & 1.03 & 47.2 & 1.02 & 44.9 & 1.01 & 50.3 & 1.03 & 47.7 \\
\hline 3 & 48.2 & 0.99 & 47.4 & 0.99 & 52.3 & 0.99 & 42.3 & 0.99 & 47.5 \\
\hline 4 & 49.3 & 0.98 & 50.1 & 0.99 & 43.5 & 0.97 & 41.2 & 0.98 & 46.0 \\
\hline 5 & 42.5 & 0.99 & 46.2 & 0.99 & 47.5 & 0.98 & 44.4 & 0.98 & 45.1 \\
\hline 6 & 42.1 & 1.03 & 45.2 & 1.04 & 48.2 & 1.03 & 43.2 & 1.01 & 44.7 \\
\hline Mean & 45.5 & & 47.5 & & 45.9 & & 44.1 & & \\
\hline \multicolumn{10}{|c|}{$\mathrm{pH}$} \\
\hline 1 & 7.2 & 0.96 & 7.4 & 0.96 & 7.3 & 0.98 & 7.6 & 1.02 & 7.4 \\
\hline 2 & 7.5 & 0.96 & 7.6 & 0.98 & 7.5 & 0.99 & 7.5 & 0.98 & 7.5 \\
\hline 3 & 7.6 & 0.99 & 7.6 & 1.00 & 7.5 & 1.02 & 7.5 & 1.02 & 7.5 \\
\hline 4 & 7.6 & 0.99 & 7.6 & 1.01 & 7.6 & 1.03 & 7.4 & 1.00 & 7.5 \\
\hline 5 & 7.5 & 0.99 & 7.6 & 0.99 & 7.5 & 1.02 & 7.5 & 1.01 & 7.5 \\
\hline 6 & 7.6 & 0.99 & 7.6 & 0.99 & 7.5 & 1.00 & 7.4 & 0.99 & 7.5 \\
\hline Mean & 7.5 & & 7.6 & & 7.5 & & 7.5 & & \\
\hline
\end{tabular}

* See: Table 1 .

The $\mathrm{pH}$ of the studied soils did not show great variability, and the mean $\mathrm{pH}$ values were in the range of 7.4-7.6. Despite the obtained results indicating a higher $\mathrm{pH}$ in the experimental plots with straw left in the field (S.1, S.2), the value of the relative change 
coefficient $>1$ suggests that collecting straw from the field (S.3, S.4) resulted in an increase in the $\mathrm{pH}$ value in the soil more often (Table 3 ).

A significantly higher number of bacteria compared to other tillage variants was reported in the cultivation variant T.6, where it reached $84.4 \times 10^{6} \mathrm{cfu} \mathrm{g}^{-1}$. The number of actinobacteria and fungi was also higher, but not always significant, in this experimental plot and reached $31.5 \times 10^{5} \mathrm{cfu} \mathrm{g}^{-1}$ and $23.7 \times 10^{4} \mathrm{cfu} \mathrm{g}^{-1}$, respectively. In the case of these groups of microorganisms, no such clear variation was observed between the cultivation systems (Table 4).

Table 4. The total number of bacteria, actinobacteria, and fungi in the soil, depending on the tillage method (factor T) and stubble management (factor $\mathrm{S}$ ) in the spring wheat cultivation.

\begin{tabular}{|c|c|c|c|c|c|}
\hline \multirow{2}{*}{$\begin{array}{c}\text { Factor } \mathbf{T} \\
\text { Variants * }\end{array}$} & \multicolumn{5}{|c|}{ Factor S Variants } \\
\hline & 1 & 2 & 3 & 4 & Mean \\
\hline & \multicolumn{5}{|c|}{ Bacteria $\left(10^{6} \mathrm{cfu} \mathrm{g}^{-1}\right)$} \\
\hline 1 & 40.5 & 48.0 & 35.2 & 34.1 & 39.4 \\
\hline 2 & 78.5 & 93.0 & 68.3 & 59.7 & 74.9 \\
\hline 3 & 45.3 & 40.9 & 41.5 & 42.9 & 42.7 \\
\hline 4 & 69.5 & 72.5 & 51.5 & 49.2 & 60.7 \\
\hline 5 & 56.3 & 57.9 & 49.0 & 51.0 & 53.6 \\
\hline 6 & 89.3 & 92.8 & 75.8 & 79.6 & 84.4 \\
\hline Mean & 63.3 & 67.5 & 53.5 & 52.7 & \\
\hline \multicolumn{6}{|c|}{$\mathrm{LSD}_{0.05}$ for: Factor $\mathrm{T}=6.4 ;$ Factor $\mathrm{S}=8.7 ;$ Interaction $\mathrm{T} / \mathrm{S}=12.7 ; \mathrm{S} / \mathrm{T}=13.4 * *$} \\
\hline & \multicolumn{5}{|c|}{ Actinobacteria $\left(10^{5} \mathrm{cfu} \mathrm{g}^{-1}\right)$} \\
\hline 1 & 30.4 & 30.4 & 26.6 & 19.7 & 26.8 \\
\hline 2 & 30.1 & 30.1 & 26.3 & 19.5 & 26.5 \\
\hline 3 & 25.6 & 34.6 & 21.1 & 20.8 & 25.5 \\
\hline 4 & 27.6 & 29.0 & 30.7 & 25.8 & 28.3 \\
\hline 5 & 29.8 & 28.1 & 29.4 & 27.7 & 28.8 \\
\hline 6 & 32.4 & 40.7 & 27.1 & 25.6 & 31.5 \\
\hline Mean & 29.3 & 32.1 & 26.9 & 23.2 & \\
\hline \multicolumn{6}{|c|}{$\mathrm{LSD}_{0.05}$ for: Factor $\mathrm{T}=3.9 ;$ Factor $\mathrm{S}=4.2 ;$ Interaction $\mathrm{T} / \mathrm{S}=6.5 ; \mathrm{S} / \mathrm{T}=6.4$} \\
\hline & \multicolumn{5}{|c|}{ Fungi $\left(10^{4} \mathrm{cfu} \mathrm{g}^{-1}\right)$} \\
\hline 1 & 21.6 & 22.7 & 18.1 & 12.6 & 18.7 \\
\hline 2 & 26.8 & 28.1 & 22.4 & 15.6 & 23.2 \\
\hline 3 & 20.0 & 23.3 & 18.0 & 14.7 & 19.0 \\
\hline 4 & 21.5 & 26.6 & 20.0 & 17.0 & 21.3 \\
\hline 5 & 20.7 & 19.4 & 19.6 & 20.3 & 20.0 \\
\hline 6 & 23.1 & 25.5 & 23.7 & 22.5 & 23.7 \\
\hline Mean & 22.3 & 24.3 & 20.3 & 17.1 & \\
\hline
\end{tabular}

* See: Table $1,{ }^{* *}$ the significance of differences by Tukey's test, at $p \leq 0.05$.

In the soil from the experimental plots where the chopped straw was left, the number of bacteria was significantly higher than in the samples from the plots from which it was removed. Moreover, the presence of straw stimulated the growth of actinomycetes and fungi. The addition of the EM preparation increased the number of the studied groups of soil microorganisms, but a significant difference was found only with fungi in the variant in which the straw was removed from the field (Table 4).

The total number of microorganisms isolated from the studied soils was significantly higher $\left(87.7 \times 10^{6} \mathrm{cfu} \mathrm{g}^{-1}\right)$ in variant T.6. On the other hand, a significantly lower number of microorganisms was found in the T.1 and T.3 systems, i.e., traditional plowing and tillage limited to grubbing. Each of the tested experimental plots stimulated the growth of soil microorganisms, as evidenced by the relative change coefficient exceeding 1 . The highest value of the relative change coefficient, exceeding 2 regardless of the method of 
stubble management, was reported in the T.6 cultivation system, which suggests that the use of traditional cultivation in combination with fertilization with manure and catch crop results in the highest increase in the total number of microorganisms. The number of microorganisms was significantly higher in soils from plots with straw left in the field (S.1 and S.2). On the other hand, the application of the bacterial EM preparation did not affect the population size of soil microorganisms (Table 5).

Table 5. The total number of the soil microorganisms, depending on the tillage method (factor T) and stubble management (factor S) applied in the spring wheat cultivation $\left[10^{6} \mathrm{cfu} \mathrm{g}^{-1}\right]$.

\begin{tabular}{|c|c|c|c|c|c|c|c|c|c|}
\hline \multirow{3}{*}{$\begin{array}{c}\text { Factor T } \\
\text { Variants * }\end{array}$} & \multicolumn{9}{|c|}{ Factor S Variants } \\
\hline & 1 & & 2 & & 3 & & 4 & & Mean \\
\hline & count & $\mathrm{W}_{\mathrm{k}}$ & count & $\mathrm{W}_{\mathrm{k}}$ & count & $\mathrm{W}_{\mathrm{k}}$ & count & $\mathrm{W}_{\mathrm{k}}$ & \\
\hline 1 & 43.7 & 1.21 & 51.2 & 1.41 & 38.0 & 1.05 & 36.2 & 1.00 & 42.3 \\
\hline 2 & 81.8 & 2.26 & 96.3 & 2.66 & 71.1 & 1.96 & 61.8 & 1.71 & 77.8 \\
\hline 3 & 48.1 & 1.32 & 44.5 & 1.23 & 43.8 & 1.21 & 45.1 & 1.27 & 45.4 \\
\hline 4 & 72.5 & 2.0 & 75.7 & 2.09 & 54.8 & 1.51 & 51.9 & 1.43 & 63.7 \\
\hline 5 & 59.5 & 1.62 & 61.0 & 1.66 & 52.1 & 1.44 & 53.9 & 1.49 & 56.7 \\
\hline 6 & 92.8 & 2.56 & 97.1 & 2.68 & 78.7 & 2.17 & 82.4 & 2.27 & 87.7 \\
\hline Mean & 66.4 & & 71.0 & & 56.5 & & 55.2 & & \\
\hline
\end{tabular}

* See: Table $1,{ }^{* *}$ the significance of differences by Tukey's test, at $p \leq 0.05$.

Soil respiration intensity values varied from 0.236 to $0.471 \mathrm{CO}_{2} \mu \mathrm{L} \mathrm{m}^{-2} \mathrm{~h}^{-1}$ that corresponds to the number of microorganisms inhabiting this environment. The introduction of organic matter to the soil in the form of shredded straw (S.1, S.2) increased significantly the value of this parameter. The addition of manure and catch crop in T.2 and T.6 systems also stimulated significantly the soil respiration intensity (Table 6).

Table 6. Soil respiration intensity $\left(\mathrm{CO}_{2} \mu \mathrm{L} \mathrm{m}^{-2} \mathrm{~h}^{-1}\right)$, depending on tillage method (factor T) and stubble management (factor $\mathrm{S}$ ) applied in spring wheat cultivation.

\begin{tabular}{cccccc}
\hline \multirow{2}{*}{$\begin{array}{c}\text { Factor T } \\
\text { Variants }\end{array}$} & \multicolumn{5}{c}{ Factor S Variants } \\
\cline { 2 - 6 } & $\mathbf{1}$ & $\mathbf{2}$ & $\mathbf{3}$ & $\mathbf{4}$ & Mean \\
\hline 1 & 0.450 & 0.480 & 0.150 & 0.144 & 0.306 \\
2 & 0.570 & 0.540 & 0.380 & 0.395 & 0.471 \\
3 & 0.440 & 0.465 & 0.165 & 0.160 & 0.307 \\
4 & 0.433 & 0.514 & 0.163 & 0.148 & 0.315 \\
5 & 0.423 & 0.485 & 0.160 & 0.200 & 0.317 \\
6 & 0.555 & 0.519 & 0.398 & 0.390 & 0.465 \\
Mean & 0.479 & 0.501 & 0.236 & 0.239 & \\
\hline
\end{tabular}

$\mathrm{LSD}_{0.05}$ for: Factor $\mathrm{T}=0.109$. Factor $\mathrm{S}=0.223$; Interaction $\mathrm{T} / \mathrm{S}=0.149 ; \mathrm{S} / \mathrm{T}=0.237$ **

* See: Table $1,{ }^{* *}$ the significance of differences by Tukey's test, at $p \leq 0.05$.

To determine the strength of association between the studied soil parameters, i.e., the total number of microorganisms (TNM); bacteria (B); actinobacteria (A); fungi (F); soil respiratory activity (SR); $\mathrm{pH}$ in $1 \mathrm{M} \mathrm{KCl}(\mathrm{pH})$; organic carbon content (OC); plant-available phosphorus content $(\mathrm{Pa})$, potassium $(\mathrm{Ka})$, magnesium $(\mathrm{Mg})$; total nitrogen content $(\mathrm{TN})$, mineral forms of nitrogen $\mathrm{N}-\mathrm{NO}_{3}$, and $\mathrm{N}-\mathrm{NH}_{4}$ and the used tillage system and stubble management, a principal component analysis was performed-PCA (Figure 1). Based on the available data, two main components (PC1 and PC2) were distinguished, which accounted for a total variance of $63.76 \%$. Component 1 (PC1) accounts for $49.04 \%$ of the variation, indicating a significant negative correlation with TNB (-0.954), B (-0.950), F (-0.811), SR (-0.786), $\mathrm{N}-\mathrm{NH}_{4}(-0.865), \mathrm{Pa}(-0.585), \mathrm{Ka}(-0.800)$. Component 2 (PC2-14.72\%) is negatively correlated with $\mathrm{A}(-0.561)$ and $\mathrm{TN}(-0.633)$, while positively with $\mathrm{N}-\mathrm{NO}_{3}(0.695)$. Most of 
the parameters studied were significantly grouped on the PC1 side. Therefore, this component can be equated with the impact of cultivation variants and the method of stubble management on the soil.

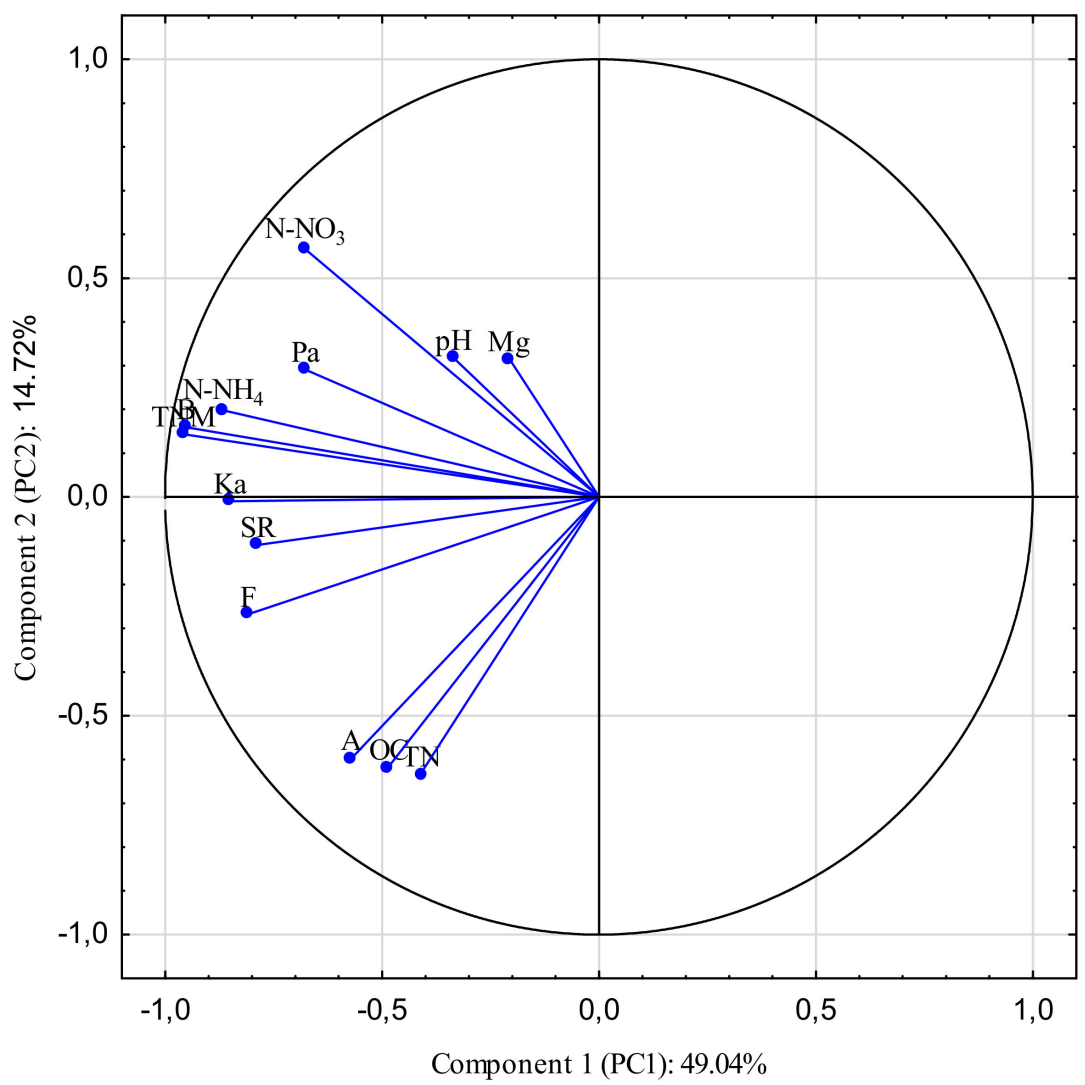

Figure 1. PCA analysis (principal component analysis PC1, PC2) of soil parameters: total number of microorganisms (TNM); bacteria (B); actinobacteria (A); fungi (F); soil respiratory activity (SR); $\mathrm{pH}$ in $1 \mathrm{M} \mathrm{KCl}(\mathrm{pH})$; organic carbon content $(\mathrm{OC})$; plant-available phosphorus content $(\mathrm{Pa})$, potassium (Ka), magnesium $(\mathrm{Mg})$; total nitrogen content $(\mathrm{TN})$, mineral forms of nitrogen: $\mathrm{N}-\mathrm{NO}_{3}$ and $\mathrm{N}-\mathrm{NH}_{4}$.

Cluster analysis performed based on Euclidean distance (Ward's method) separated the clusters based on the differentiation of variables (Figure 2). Six clusters were distinguished within the dendrogram. The greatest similarity was found between the plots T1S1, T3S1, T1S2, and T3S2 belonging to cluster 1, which are characterized by low values for most of the chemical and microbiological parameters studied. On the other hand, three plots (T2S3, T6S3 and T6S4) were placed within cluster 2 with the average values of both biological and chemical parameters (except plot T2S3, where the highest amount of available phosphorus was reported). Cluster 3 consisted of 5 plots, including T2S4, T5S1 with the highest amount of organic carbon and total and mineral forms of nitrogen. The cluster of special significance was cluster 4 , where the plots of the highest number of bacteria, actinobacteria and fungi, respiration intensity and available potassium content were grouped. Clusters 5 and 6 were the least similar to the others. Cluster 6 consisted of five plots (T3S3, T4S3, T5S3, T4S4 and T5S4), among which plots with the lowest content of available phosphorus and potassium forms were detected (Figure 2). 


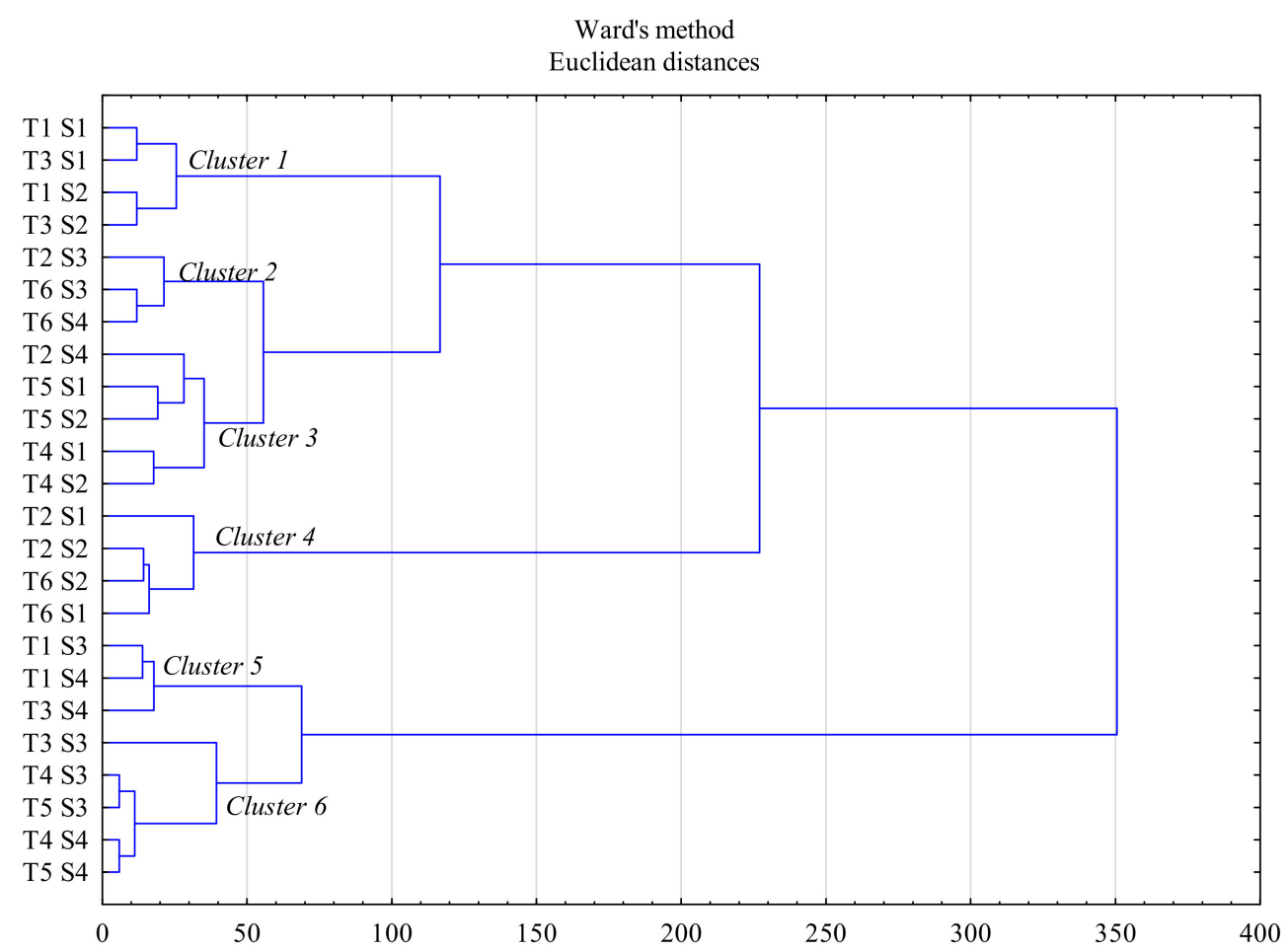

Figure 2. Dendrogram analysis of physicochemical and microbial soil characteristics, depending on the tillage method and stubble management (Factors T and S: see Table 1).

The standard gross margin value (SGM) for spring wheat was beneficially affected by zero- or reduced-tillage treatment, as well as the use of catch crops. The highest average value of this parameter was recorded in variant T.4, where it amounted to EURO 816 per hectare. The straw left on the soil surface also resulted in higher SGM values compared to those obtained on the plots with straw removed. In the soil enriched with straw, the beneficial effect of the effective microorganisms (EM) vaccine on SGM values was also found-in contrast to the objects without straw addition (Figure 3).

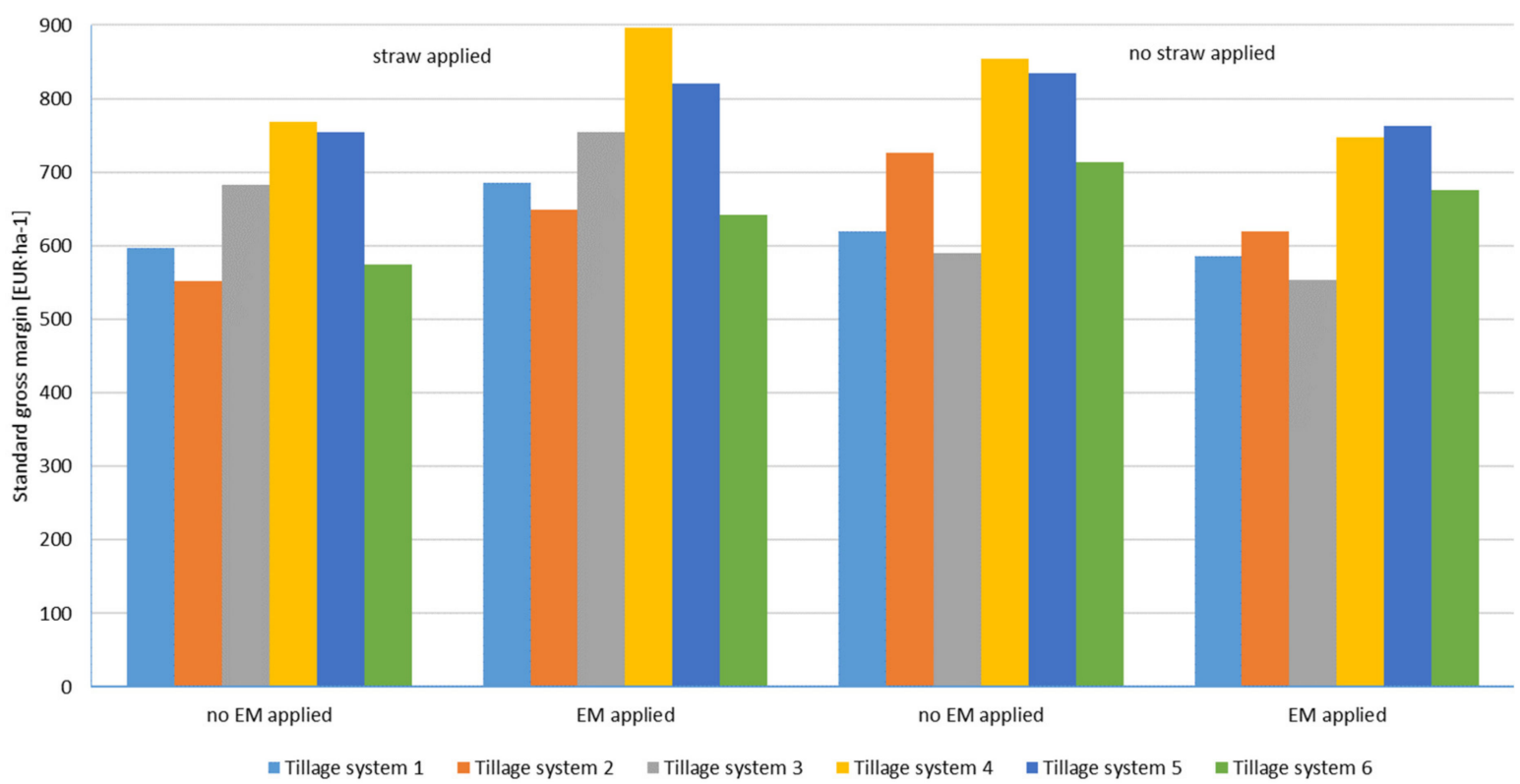

Figure 3. Standard gross margin (EUR $\cdot \mathrm{ha}^{-1}$ ) spring wheat depending on the tillage method (Factors T and S: see Table 1). 


\section{Discussion}

The modifications of the tillage system help the farmers to achieve sustainability of agricultural production. The application of various technologies results in different resource uses and environmental impacts. According to Hawes et al. [45], to achieve sustainable agricultural production, it is necessary to understand both individual processes within the cropping system as well as the whole system that are long-term responses to modifications in land administration. Intensive agriculture adopted unfriendly environmental practices resulting in severe resource degradation and GHG emissions and contributing to the higher use of energy. On the other hand, the reduction in the soil cultivation system generates savings in the direct energy input and also has a positive impact on the level of $\mathrm{CO}_{2}$ emissions to the atmosphere. The reduced tillage simplification of agrotechniques can also beneficially affect the properties of the soil environment, including the amount of soil organic carbon (SOC) $[46,47]$.

Ozpinar and Cay [48] observed that the content of organic carbon in the soil after simplified tillage was higher than in the conventional system $\left(11.5 \mathrm{~g} \cdot \mathrm{kg}^{-1}\right.$ and $8.8 \mathrm{~g} \cdot \mathrm{kg}^{-1}$, respectively). According to Powlson et al. [32], the mean annual increase in SOC, resulting from the application of simplified tillage, may reach $310 \mathrm{C} \mathrm{kg} \pm 180 \mathrm{C} \mathrm{kg} \mathrm{ha}{ }^{-1}$. Chen et al. [49] reported that reduced-tillage resulted in a 30\% increase in soil organic carbon compared to conventional management. The increase in the amount of organic matter in the soil from reduced-tillage cultivation results mainly from the slow mineralization rate of the organic substance introduced into the soil but also depends on the duration of application of such a system [48]. Changes in the amount of SOM in response to cultivation practices occur gradually, and their unambiguous direction can be determined only after a long time [50]. A multi-year experiment by Nouri et al. [11] proved that the most stable yield benefits from no-tillage appear after 10 years of cultivation. A relatively short duration of the present research may be a cause of the results indicating the lowest $\left(19.1 \mathrm{OC} \mathrm{g} \mathrm{kg}^{-1}\right)$ organic carbon content in the variant of no-tillage cultivation (T.3), reduced to grubbing (Table 1). The lowest amount of total nitrogen TN $\left(16.8 \mathrm{~N} \mathrm{~g} \mathrm{~kg}^{-1}\right)$ was also found in the soil of the experimental plots where this system was applied. At the same time, similar, very low values determining the amounts of both $\mathrm{SOC}, \mathrm{TN}$, and other analyzed parameters (e.g., the total number of microorganisms) were observed after the use of the traditional plowing system (T.1) (Tables 1 and 5). The dendrogram showing the relationships between the various cultivation and stubble management systems confirmed that the T1S1, T3S1, T1S2, T3S2 variants belong to one cluster, characterized by the low values for most chemical and microbiological parameters (Figure 2). These results lead to the conclusion that in the present study, the level of the applied simplification methods of the cultivation system was not of key importance for the values of the aforementioned indicators characterizing the studied soils. On the other hand, the addition of organic matter to the soil in the form of manure (T.2, T.6), catch crop biomass (T.4, T.5, T.6), or shredded straw (S.1, S.2), used together or separately, had a much greater impact.

A large share of cereals in the crop's structure results in the reduction in organic matter content in soil. Manure fertilization contributes to the optimization of the amount of soil organic carbon and organic matter [25]. An increase in the concentration of SOC by on average $60 \pm 20 \mathrm{C} \mathrm{kg} \mathrm{ha}^{-1} \mathrm{yr}^{-1} \mathrm{t}^{-1}$ as a result of manure addition was reported by Powlson et al. [32]. In the present study, apart from the high content of SOC and TN in soils fertilized with manure, the highest amounts of plant-available phosphorus and potassium, exceeding 200 and $400 \mathrm{mg} \mathrm{kg}^{-1} \mathrm{~d} . \mathrm{m}$. soil, respectively, were found (Table 3). Han et al. [51] reported a growth in the content of organic carbon, nitrogen, available phosphorus, exchangeable potassium, and magnesium in the manure-fertilized soil. The positive correlation between the use of manure and the amount of nitrogen, phosphorus, and potassium in the soil was also confirmed by Kaur et al. [52].

The fertilization with manure and application of catch crop in the cultivation variant T.6 stimulated the soil biological activity, from which the highest total number of microorganisms was isolated, reaching $87.7 \times 10^{6} \mathrm{cfu} \mathrm{g}^{-1}$ (Table 5). Both the intensification and 
limitation of the cultivation method may significantly alter the proportions of individual groups of soil microorganisms and relationships between various members of these groups. The degradation of the soil environment resulting from intensive agriculture practices increases the risk of biodiversity loss [53]. According to Jaskulska et al. [54], the number of soil bacteria and fungi after changing the conventional tillage system with simplified cultivation increased by $17.3 \%$ and $45.1 \%$, respectively. No such influence was found in the present research, which confirms that, as in the case of chemical parameters, the intensity of cultivation had only a limited impact on the size of the population of both individual groups of microorganisms and the total number of microorganisms (Tables 4 and 5). The association between the number of microorganisms and other indicators characterizing the soils in the investigated cultivation variants was analyzed using the PCA method (Figure 1). The analysis of the main components showed that the number of bacteria $B(r=0.664)$, actinobacteria A $(r=0.537)$, and filamentous fungi $F(0.761)$ increased with the rise in soil respiration (SR) intensity. Many studies confirm the direct correlation between the level of respiration and soil microbial activity, and soil basal respiration is applied to study the soil microbial activity $[55,56]$. In the present study, the highest value of respiration intensity $\left(450 \mathrm{CO}_{2} \mu \mathrm{L} \mathrm{m}^{-2} \mathrm{~h}^{-1}\right)$ was reported in system T.6, where the highest number of microorganisms was also found (Tables 5 and 6). The number of bacteria was significantly correlated with the content of nitrate nitrogen $(r=0.731)$ and ammonium nitrogen $(r=0.889)$. A positive association was also reported between the content of available phosphorus and the number of bacteria $(\mathrm{r}=0.655)$, amount of $\mathrm{N}^{-\mathrm{NO}_{3}}(\mathrm{r}=0.630)$, and $\mathrm{N}-\mathrm{NH}_{4}$ $(\mathrm{r}=0.629)$ (Figure 1).

The enrichment of the soil environment with organic matter originating from crop residues left on the surface is a reasonable and environmentally desirable activity. Cereal straw, as a valuable source of organic carbon, can significantly increase its amount in soil $[3,57]$. In soil supplemented for 18 years with straw in a dose of $12 \mathrm{t} \mathrm{ha}^{-1}$, the amount of carbon was $1 / 3$ higher annually than that found in the soil without the addition of this material [58]. Long-term no-tillage management combined with surface residue mulching increased the SOC in some soils in the research by Blanco-Canqui and Lal [59]. The results of the present study confirm higher values of the amount of SOC if the shredded straw was applied to the soil. In these experimental variants (S.1, S.2), higher, always $>1$, values of the coefficient of relative change in the organic carbon content were observed, suggesting the stimulating effect of this method of stubble management on the amount of organic carbon in the soil (Table 1). Removal of straw from the experimental plots resulted in a decrease in the potassium content, a significant reduction in the number of bacteria and the total number of microorganisms, and a reduction in the intensity of soil respiration activity (Tables 3-6). The effect of straw on the content of nitrogen, phosphorus, and magnesium was less significant (Table 3).

The application of microbiological biopreparations aims at the improvement of physicochemical properties and biological activity of arable soils. According to the primary conception, Effective Microorganisms (EM) vaccines introduced into the soil are supposed to beneficially affect the soil characteristic and, ultimately, yield amount and quality [60,61]. However, the results of the present research on the effect of the bacterial vaccine on the content of carbon, nitrogen, and other elements studied do not confirm any clear tendencies determining these relations (Tables 1-3). The differences between the mean values of these parameters, resulting from the use of EM, were statistically significant in only a few cases, which allows the underestimation of the role of these preparations in the context of improving the chemical properties of the soil. Similar conclusions also refer to the number of soil microorganisms and the intensity of soil respiration (Tables 4-6). The EM application led to an increase in the number of the studied groups of microorganisms in the soil; however, statistically significant differences concerned only filamentous fungi in the variant in which straw was removed (S.3, S.4) (Table 4). Szymanek et al. [62] claim that the action of EM led to a decrease in the amount of phosphorus, potassium, and magnesium in the soil. 
On the other hand, several studies are indicating the possible positive effect of bacterial preparations on the mineral balance in the soil and its phytosanitary condition $[63,64]$.

The standard gross margin value (SGM) calculated for the spring wheat in the present study was positively affected by zero or reduced tillage systems and straw addition (Figure 3). Glenk et al. [65] reported that reduced and zero tillage practices decreased farm gross margins initially as a result of the delayed yield effects. In later years, however, crop yields increased by $5 \%$, accompanied by positive gross margin effects. Animal manures application showed positive gross margin effects; however, organic matter management may also result in cost increase related to additional requirements for fuel or labor. According to Cook et al. [66], variability of the factors related to farm organic matter management makes the precise estimation of its economic cost or benefit a great challenge.

\section{Conclusions}

Simplifying tillage systems to neutralize the negative effects of intensive farming practice is considered one of the key elements of a sustainable agriculture strategy. The present research suggests that while the diversification of cultivation treatments in terms of their quantity and the level of soil inversion can influence the values of the key chemical and biological parameters for soil fertility, the selection of an appropriate method of supplementing soil organic matter seems to have a much greater impact. This statement is supported by the relatively low content of organic carbon, total nitrogen, and the number of microorganisms reported in both the traditional T.1 system and the T.3 system limited to grubbing. The link between these two tillage systems was the lack of any additional supplementation of the soil with organic matter. Another argument supporting the hypothesis that additional sources of organic compounds are of key importance for soil parameters are the results of soil analyses in the variants with manure fertilization (T.2 and T.6), in which high, and often the highest, levels of nutrients and soil microbial abundance were found. The method of stubble management, based on leaving shredded straw in the field, had an undoubtedly positive effect on the organic carbon content and soil microbiological activity.

The obtained results suggest that modification of the cultivation systems intensity requires simultaneous consideration of treatments optimizing the potentially negative impact on the properties of the soil environment. Supplementing the soil with various sources of organic matter allows to improve the parameters determining soil productivity and effectively manage the excess of produced biomass, e.g., by introducing crop residues into the soil, e.g., shredded straw. The limitations of the research may result from a relatively short duration of the experiments, as well as, typical for field research, specificity related to the location of experimental plots.

Author Contributions: Conceptualization, K.K. and B.B.-B.; methodology, K.K. and B.B.-B.; investigation, K.K.; data curation-compiled and analyzed the results, B.B.-B. and K.K.; writing-original draft preparation, B.B.-B., J.B.-K. and K.K.; review and editing, B.B.-B., J.B.-K. and K.K. All authors have read and agreed to the published version of the manuscript.

Funding: The study was carried out as part of our research project PB-7294/B/P01/2011/40.

Institutional Review Board Statement: Not applicable.

Informed Consent Statement: Not applicable.

Data Availability Statement: Not applicable.

Conflicts of Interest: The authors declare no conflict of interest. 


\section{References}

1. Williams, A.; van der Bom, F.; Young, A.J. Resilient and dynamic soil biology. In No-Till Farming Systems for Sustainable Agriculture: Challenges and Opportunities; Dang, Y.P., Dalal, R.C., Menzies, N.W., Eds.; Springer International Publishing: Cham, Switzerland, 2020; pp. 251-266.

2. Sokolowski, A.C.; McCormick, B.P.; de Grazia, J.; Wolski, J.E.; Rodríguez, H.A.; Rodríguez-Frers, E.P.; Gagey, M.C.; Debelis, S.P.; Paladino, I.R.; Barrios, M.B. Tillage and no-tillage effects on physical and chemical properties of an Argiaquoll soil under long-term crop rotation in Buenos Aires, Argentina. Int. Soil Water Conserv. Res. 2020, 8, 185-194. [CrossRef]

3. Schlesinger, W.H.; Amundson, R. Managing for soil carbon sequestration: Let's get realistic. Glob. Chang. Biol. 2018, 25, 386-389. [CrossRef] [PubMed]

4. Woźniak, A.; Rachoń, L. Effect of Tillage Systems on the Yield and Quality of Winter Wheat Grain and Soil Properties. Agriculture 2020, 10, 405. [CrossRef]

5. Blanco-Canqui, H.; Ruis, S.J. No-tillage and soil physical environment. Geoderma 2018, 326, 164-200. [CrossRef]

6. Liu, Z.; Cao, S.; Sun, Z.; Wang, H.; Qu, S.; Lei, N.; He, J.; Dong, Q. Tillage effects on soil properties and crop yield after land reclamation. Sci. Rep. 2021, 11, 1-12. [CrossRef]

7. Haruna, S.; Nkongolo, N. Effects of Tillage, Rotation and Cover Crop on the Physical Properties of a Silt-Loam Soil. Int. Agrophysics 2015, 29, 137-145. [CrossRef]

8. Sandén, T.; Spiegel, H.; Stüger, H.-P.; Schlatter, N.; Haslmayr, H.-P.; Zavattaro, L.; Grignani, C.; Bechini, L.; Hose, T.; Molendijk, L.; et al. European long-term field experiments: Knowledge gained about alternative management practices. Soil Use Manag. 2018, 34 , 167-176. [CrossRef]

9. Dang, Y.P.; Page, K.L.; Dalal, R.C.; Menzies, N.W. No-till Farming Systems for Sustainable Agriculture: An Overview. In No-Till Farming Systems for Sustainable Agriculture: Challenges and Opportunities; Dang, Y.P., Dalal, R.C., Menzies, N.W., Eds.; Springer International Publishing: Cham, Switzerland, 2020; pp. 3-20.

10. Gülser, F.; Salem, S.; Gülser, C. Changes in some soil properties of wheat fields under conventional and reduced tillage systems in Northern Iraq. Eurasian J. Soil Sci. 2020, 9, 314-320. [CrossRef]

11. Nouri, A.; Lee, J.; Yoder, D.C.; Jagadamma, S.; Walker, F.R.; Yin, X.; Arelli, P. Management duration controls the synergistic effect of tillage, cover crop, and nitrogen rate on cotton yield and yield stability. Agric. Ecosyst. Environ. 2020, 301, 107007. [CrossRef]

12. Coonan, E.; Richardson, A.E.; Kirkby, C.A.; Kirkegaard, J.; Amidy, M.; Strong, C.L. Soil fertility and nutrients mediate soil carbon dynamics following residue incorporation. Nutr. Cycl. Agroecosyst. 2019, 116, 205-221. [CrossRef]

13. Amanullah; Khalid, S.; Imran; Khan, H.A.; Arif, M.; Altawaha, A.R.; Adnan, M.; Fahad, S.; Parmar, B. Organic Matter Management in Cereals Based System: Symbiosis for Improving Crop Productivity and Soil Health. Sustain. Agric. Rev. 2019, $29,67-92$. [CrossRef]

14. Food and Agriculture Organization of United Nations. FAO Cereal Supply and Demand Brief. 2021. Available online: http: / /www.fao.org/worldfoodsituation/csdb/en/ (accessed on 27 September 2021).

15. Lithourgidis, A.S.; Damalas, C.A.; Eleftherohorinos, I.G. Conservation Tillage: A Promising Perspective for Sustainable Agriculture in Greece. J. Sustain. Agric. 2009, 33, 85-95. [CrossRef]

16. Moraru, P.; Rusu, T.; Paulette, L.; Buta, M.; Oroian, I.; Odagiu, A.; Clapa, D.; Cosma, S. Reducing Energy Consumption and Soil Conservation by Tillage System. ProEnviron. Promediu 2013, 6, 164-170.

17. Moitzi, G.; Neugschwandtner, R.W.; Kaul, H.-P.; Wagentristl, H. Effect of tillage systems on energy input and energy efficiency for sugar beet and soybean under Pannonian climate conditions. Plant. Soil Environ. 2021, 67, 137-146. [CrossRef]

18. Ribera, L.A.; Hons, F.M.; Richardson, J.W. An economic comparison between conventional and no-tillage farming systems in Burleson County Texas. Agron. J. 2004, 96, 415-424. [CrossRef]

19. Jat, M.L.; Dagar, J.C.; Sapkota, T.B.; Singh, Y.; Govaerts, B.; Ridaura, S.L.; Saharawat, Y.S.; Sharma, R.K.; Tetarwal, J.P.; Jat, R.K.; et al. Climate Change and Agriculture: Adaptation Strategies and Mitigation Opportunities for Food Security in South Asia and Latin America. Adv. Agron. 2016, 137, 127-235.

20. Šarauskis, E.; Buragienè, S.; Masilionytè, L.; Romaneckas, K.; Avižienytė, D.; Sakalauskas, A. Energy balance, costs and CO 2 analysis of tillage technologies in maize cultivation. Energy 2014, 69, 227-235. [CrossRef]

21. Fuentes-Llanillo, R.; Telles, T.S.; Junior, D.S.; de Melo, T.R.; Friedrich, T.; Kassam, A. Expansion of no-tillage practice in conservation agriculture in Brazil. Soil Tillage Res. 2020, 208, 104877. [CrossRef]

22. Schjønning, P.; Jensen, J.L.; Bruun, S.; Jensen, L.S.; Christensen, B.T.; Munkholm, L.J.; Oelofse, M.; Baby, S.; Knudsen, L. The Role of Soil Organic Matter for Maintaining Crop Yields: Evidence for a Renewed Conceptual Basis. Adv. Agron. 2018, 150, 35-79. [CrossRef]

23. Rusu, T. Energy efficiency and soil conservation in conventional, minimum tillage and no-tillage. Int. Soil Water Conserv. Res. 2014, 2, 42-49. [CrossRef]

24. Gan, Y.; Siddique, K.H.; Turner, N.C.; Li, X.-G.; Niu, J.-Y.; Yang, C.; Liu, L.; Chai, Q. Ridge-Furrow Mulching Systems-An Innovative Technique for Boosting Crop Productivity in Semiarid Rain-Fed Environments. Adv. Agron. 2013, 118, 429-476. [CrossRef]

25. Viaud, V.; Angers, D.A.; Parnaudeau, V.; Morvan, T.; Aubry, S.M. Response of organic matter to reduced tillage and animal manure in a temperate loamy soil. Soil Use Manag. 2010, 27, 84-93. [CrossRef] 
26. Jacoby, R.; Peukert, M.; Succurro, A.; Koprivova, A.; Kopriva, S. The Role of Soil Microorganisms in Plant Mineral NutritionCurrent Knowledge and Future Directions. Front. Plant. Sci. 2017, 8, 1617. [CrossRef] [PubMed]

27. Ramesh, T.; Bolan, N.S.; Kirkham, M.B.; Wijesekara, H.; Kanchikerimath, M.; Rao, C.S.; Sandeep, S.; Rinklebe, J.; Ok, Y.S.; Choudhury, B.U.; et al. Soil organic carbon dynamics: Impact of land use changes and management practices: A review. Adv. Agron. 2019, 156, 1-107. [CrossRef]

28. Coonan, E.; Kirkby, C.A.; Kirkegaard, J.A.; Amidy, M.R.; Strong, C.L.; Richardson, A.E. Microorganisms and nutrient stoichiometry as mediators of soil organic matter dynamics. Nutr. Cycl. Agroecosyst. 2020, 117, 273-298. [CrossRef]

29. Qin, J.; Liu, H.; Zhao, J.; Wang, H.; Zhang, H.; Yang, D.; Zhang, N. The Roles of Bacteria in Soil Organic Carbon Accumulation under Nitrogen Deposition in Stipa baicalensis Steppe. Microorganisms 2020, 8, 326. [CrossRef] [PubMed]

30. Sun, R.; Li, W.; Dong, W.; Tian, Y.; Hu, C.; Liu, B. Tillage Changes Vertical Distribution of Soil Bacterial and Fungal Communities. Front. Microbiol. 2018, 9, 699. [CrossRef]

31. Buerkert, A.; Joergensen, R.; Ludwig, B.; Schlecht, E. Nutrient and Carbon Fluxes in Terrestrial Agro-Ecosystems. In Marschners Mineral Nutrition of Higher Plants; Marschner, P., Ed.; Elsevier: Amsterdam, The Netherlands; Academic Press: Cambridge, MA, USA, 2012; pp. 473-482.

32. Powlson, D.; Bhogal, A.; Chambers, B.; Coleman, K.; Macdonald, A.; Goulding, K.; Whitmore, A. The potential to increase soil carbon stocks through reduced tillage or organic material additions in England and Wales: A case study. Agric. Ecosyst. Environ. 2012, 146, 23-33. [CrossRef]

33. Stockfisch, N.; Forstreuter, T.; Ehlers, W. Ploughing effects on soil organic matter after twenty years of conservation tillage in Lower Saxony, Germany. Soil Tillage Res. 1999, 52, 91-101. [CrossRef]

34. Afanador-Barajas, L.N.; Navarro-Noya, Y.E.; Luna-Guido, M.L.; Dendooven, L. Impact of a bacterial consortium on the soil bacterial community structure and maize (Zea mays L.) cultivation. Sci. Rep. 2021, 11, 1-13. [CrossRef]

35. Javaid, A. Effects of Biofertilizers Combined with Different Soil Amendments on Potted Rice Plants. Chil. J. Agric. Res. 2011, 71, 157-163. [CrossRef]

36. Kotwica, K.; Jaskulska, I.; Gałęzewski, L.; Jaskulski, D.; Lamparski, R. Spring wheat yield in short-term monoculture depending on the tillage method, use of organic matter and a biostimulant. Acta Sci. Pol. Agric. 2014, 13, 19-28.

37. PN-ISO 10390. Chemical and Agricultural Analysis—Determining Soil pH; Polish Standards Committee: Warszawa, Poland, 1997.

38. PN-R-04023. Chemical and Agricultural Analysis-Determination of the Content of Available Phosphorus in Mineral Soils; Polish Standards Committee: Warszawa, Poland, 1996.

39. PN-R-04022. Chemical and Agricultural Analysis_Determination of the Content Available Potassium in Mineral Soils; Polish Standards Committee: Warszawa, Poland, 1996.

40. PN-R-04020. Chemical and Agricultural Analysis. Determination of the Content Available Magnesium; Polish Standards Committee: Warszawa, Poland, 1994.

41. Atlas, R.M. Handbook of Microbiological Media, 4th ed.; CRC Press: Boca Raton, FL, USA; Taylor \& Francis Group: Abingdon, UK, 2010

42. Crawford, D.L.; Lynch, J.M.; Whipps, J.M.; Ousley, M.A. Isolation and Characterization of Actinomycete Antagonists of a Fungal Root Pathogen. Appl. Environ. Microbiol. 1993, 59, 3899-3905. [CrossRef] [PubMed]

43. Farm Accountancy Data Network. Available online: http://fadn.pl/en/ (accessed on 23 October 2021).

44. Statistica, Data Analysis Software System, version 12; TIBCO Software Inc.: Palo Alto, CA, USA, 2019. Available online: https: //www.tibco.com/products/data-science(accessed on 28 September 2021).

45. Hawes, C.; Alexander, C.J.; Begg, G.S.; Iannetta, P.P.M.; Karley, A.J.; Squire, G.R.; Young, M. Plant Responses to an Integrated Cropping System Designed to Maintain Yield Whilst Enhancing Soil Properties and Biodiversity. Agronomy 2018, 8, 229. [CrossRef]

46. Sørensen, C.G.; Halberg, N.; Oudshoorn, F.W.; Petersen, B.M.; Dalgaard, R. Energy inputs and GHG emissions of tillage systems Biosyst. Eng. 2014, 120, 2-14. [CrossRef]

47. Parcerisas, L.; Dupras, J. From mixed farming to intensive agriculture: Energy profiles of agriculture in Quebec, Canada, 1871-2011. Reg. Environ. Change 2018, 18, 1047-1057. [CrossRef]

48. Özpinar, S.; Çay, A. Effects of minimum and conventional tillage systems on soil properties and yield of winter wheat (Triticum aestivum L.) in clay-loam in Çanakkale region. Turk. J. Agric. For. 2005, 29, 9-18.

49. Chen, J.; Zhu, R.; Zhang, Q.; Kong, X.; Sun, D. Reduced-tillage management enhances soil properties and crop yields in a alfalfa-corn rotation: Case study of the Songnen Plain, China. Sci. Rep. 2019, 9, 17064. [CrossRef]

50. Varvel, G.E.; Wilhelm, W. No-tillage increases soil profile carbon and nitrogen under long-term rainfed cropping systems. Soil Tillage Res. 2011, 114, 28-36. [CrossRef]

51. Han, S.H.; An, J.Y.; Hwang, J.; Bin Kim, S.; Park, B.B. The effects of organic manure and chemical fertilizer on the growth and nutrient concentrations of yellow poplar (Liriodendron tulipifera Lin.) in a nursery system. For. Sci. Technol. 2016, 12, 137-143. [CrossRef]

52. Kaur, K.; Kapoor, K.K.; Gupta, A.P. Impact of organic manures with and without mineral fertilizers on soil chemical and biological properties under tropical conditions. J. Plant. Nutr. Soil Sci. 2005, 168, 117-122. [CrossRef]

53. Furtak, K.; Gajda, A.M. Activity and Variety of Soil Microorganisms Depending on the Diversity of the Soil Tillage System. In Sustainability of Agroecosystems; de Oliveira, A.B., Ed.; IntechOpen: London, UK, 2018. [CrossRef]

54. Jaskulska, I.; Romaneckas, K.; Jaskulski, D.; Gałęzewski, L.; Breza-Boruta, B.; Dębska, B.; Lemanowicz, J. Soil Properties after Eight Years of the Use of Strip-Till One-Pass Technology. Agronomy 2020, 10, 1596. [CrossRef] 
55. Allison, S.D.; Czimczik, C.I.; Treseder, K.K. Microbial activity and soil respiration under nitrogen addition in Alaskan boreal forest. Glob. Chang. Biol. 2008, 14, 1156-1168. [CrossRef]

56. Jia, X.; Cao, H.; Jiang, L.; Yuan, J.; Zheng, S. Comparison of heat output and $\mathrm{CO}_{2}$ respiration to assess soil microbial activity: A case of ultisol soil. Plant Soil Environ. 2018, 64, 470-478.

57. Mühlbachová, G.; Růžek, P.; Kusá, H.; Vavera, R.; Káš, M. Winter Wheat Straw Decomposition under Different Nitrogen Fertilizers. Agriculture 2021, 11, 83. [CrossRef]

58. Thomsen, I.K.; Christensen, B.T. Yields of wheat and soil carbon and nitrogen contents following long-term incorporation of barley straw and ryegrass catch crops. Soil Use Manag. 2004, 20, 432-438. [CrossRef]

59. Blanco-Canqui, H.; Lal, R. No-Tillage and Soil-Profile Carbon Sequestration: An On-Farm Assessment. Soil Sci. Soc. Am. J. 2008, 72, 693-701. [CrossRef]

60. Higa, T. Effective microorganisms: A biotechnology for mankind. In Proceedings of the 1st International Conference on Kyusei Nature Farming, KhonKaen, Thailand, 19-21 October 1989; Parr, J.F., Hornick, S.B., Whitman, S.E., Eds.; USA Department of Agriculture: Washington, DC, USA, 1991; pp. 8-14.

61. Dos Santos, L.F.; Lana, R.P.; Da Silva, M.C.; Veloso, T.G.; Kasuya, M.C.M.; Ribeiro, K.G. Effective microorganisms inoculant: Diversity and effect on the germination of palisade grass seeds. An. Acad. Bras. Cienc. 2020, 92, e20180426. [CrossRef]

62. Szymanek, M.; Dziwulska-Hunek, A.; Zarajczyk, J.; Michałek, S.; Tanaś, W. The Influence of Red Light (RL) and Effective Microorganism (EM) Application on Soil Properties, Yield, and Quality in Wheat Cultivation. Agronomy 2020, 10, 1201. [CrossRef]

63. Hu, C.; Qi, Y. Long-term effective microorganisms application promote growth and increase yields and nutrition of wheat in China. Eur. J. Agron. 2013, 46, 63-67. [CrossRef]

64. Mi, Y.; Zhao, X.; Liu, F.; Sun, C.; Sun, Z.; Liu, L. Changes in soil quality, bacterial community and anti-pepper Phytophthora disease ability after combined application of straw and multifunctional composite bacterial strains. Eur. J. Soil Biol. 2021, 105, 103329. [CrossRef]

65. Glenk, K.; Shrestha, S.; Topp, C.F.; Sánchez, B.; Iglesias, A.; Dibari, C.; Merante, P. A farm level approach to explore farm gross margin effects of soil organic carbon management. Agric. Syst. 2017, 151, 33-46. [CrossRef]

66. Cook, S.; Nicholson, F.; Kindred, D.; Bhogal, A.; Roques, S.; Kerley, J.; Twining, S.; Brassington, T.; Gladders, P.; Balshaw, H.; et al. Straw Incorporation Review; Technical Report No. 81; Home-Grown Cereals Authority: Warwickshire, UK, 2013. [CrossRef] 